\title{
Intensi Perawat Melakukan Pencegahan Luka Tekan di Ruang Intensif berdasarkan Theory Planned of Behaviour
}

\author{
Ristina Mirwanti' ${ }^{1}$ M.Z. Arifin ${ }^{2}$, Hana Rizamadewi Agustina $^{3}$ \\ ${ }^{1,3}$ Fakultas Keperawatan, Universitas Padjadjaran \\ ${ }^{2}$ RSUP Dr. Hasan Sadikin Bandung \\ E-mail: ristina.mirwanti@fkep.unpad.ac.id
}

\begin{abstract}
Abstrak
Luka tekan merupakan salah satu dampak hospitalisasi pada pasien kritis. Perawat memiliki peran yang penting dalam pencegahan luka tekan tetapi banyak perawat yang belum melakukan upaya pencegahan luka tekan secara maksimal sehingga perlu kajian untuk mengetahui faktor--faktor yang memengaruhinya. Intensi merupakan antiseden terdekat dengan perilaku seseorang. Berdasarkan Theory of Planned Behavior (TPB), intensi seseorang untuk melakukan sesuatu dipengaruhi oleh sikap, norma subyektif, dan pengendalian perilaku. Penelitian ini bertujuan untuk mengetahui faktor yang memengaruhi intensi perawat melakukan pencegahan luka tekan. Penelitian kuantitatif ini menggunakan deskriptif analinitik observasional dengan pendekatan korelasional dilakukan secara cross sectional. Populasi pada penelitian ini adalah perawat yang melakukan asuhan keperawatan langsung pada pasien di ruang perawatan intensif. Teknik pengambilan sampel dengan menggunakan total sampling, yaitu 70 perawat di ruang perawatan intensif. Hasil penelitian ini menunjukkan adanya hubungan antara sikap dengan intensi $(\mathrm{r}=0,632, \mathrm{p}<$ $0,05)$, norma subyektif dengan intensi $(r=0,625, p<0,05)$, dan pengendalian perilaku dengan intensi $(r=0,633$, $\mathrm{p}<0,05$ ). Semakin favorable sikap perawat maka akan semakin tinggi intensi perawat melakukan pencegahan luka tekan. Semakin tinggi tekanan normatif dari sekitar perawat maka akan semakin tinggi pula intensi perawat, dan semakin tinggi pengendalian perilaku yang dirasakan perawat maka akan semakin tinggi pula intens perawat.
\end{abstract}

Kata kunci: Intensi, pencegahan luka tekan, perawat, ruang intensif.

\section{Nurses' Intention to Prevent Pressure Ulcers in ICU based on Theory of Planned Behaviour}

\begin{abstract}
Pressure ulcer is one of the effects of hospitalization in critically-ill patients. Nurses have an important role in preventing pressure ulcer but many nurses do not implement preventive measures well. Factors influencing it need to be studied. Intention is the closest antecedent to behaviour. Based on the Theory of Planned Behavior (TPB), intention to do something is influenced by attitude, subjective norms, and perceived behavior control (PBC). The purpose of this study was to examine the relationship among antecedents: attitude, subjective norm, perceived behavior control and the intention of nurses to prevent pressure ulcer. This research was a correlational study using observational analytic description design with cross sectional approach. Population of this study was nurses who worked in the intensive care unit. Total sampling technique was used to select 70 nurses. Results of this study showed there was relationship between attitude and intention $(\mathrm{r}=0.632, \mathrm{P}<0.05)$, subjective norms and intention $(\mathrm{r}=0.625, \mathrm{P}<0.05)$, and PBC and intention $(\mathrm{r}=0.633, \mathrm{p}<0.05)$. The more favorable the attitude, the higher the intention to prevent pressure ulcer. The higher the normative pressure from surrounding nurses, the higher the intention. The higher the perceived behavioral control, the higher the intention to prevent pressure ulcer.
\end{abstract}

Key words: Intense, intensive care unit, nurse, pressure ulcer prevention. 
Ristina Mirwanti: Intensi Perawat melakukan Pencegahan Luka Tekan

\section{Pendahuluan}

Pasien di ruang perawatan intensif merupakan pasien dengan sakit berat dan kritis, cedera dengan penyulit yang mengancam nyawa (Depkes, 2006) yang membutuhkan perawatan intensif serta pemantauan yang ketat sehingga membutuhkan hospitalisasi. Salah satu dampak hospitalisasi pasien kritis dengan gangguan mobilisasi yaitu terjadinya luka tekan. Menurut Elliot, McKinley, dan Fox (2008) pasien dengan penyakit kritis memiliki risiko tinggi mengalami luka tekan. Luka tekan merupakan sebuah ancaman tambahan yang mengerikan pada pasien kritis karena kondisi fisiologinya telah menurun (Cox, 2011).

Luka tekan merupakan kerusakan terlokalisir pada bagian kulit dan/atau jaringan di bawahnya sebagai akibat dari tekanan atau tekanan bersamaan dengan robekan yang biasanya pada daerah tulang yang menonjol (National Pressure Ulcer Advisory Panel, 2012). Faktor-faktor yang memengaruhi kejadian luka tekan pada pasien antara lain penurunan mobilitas, penurunan aktifitas, penurunan persepsi sensori, kelembaban, gesekan, tenaga yang merobek, status nutrisi, usia, penurunan tekanan arteriol, stres emosional, merokok, dan temperatur kulit (Bergstrom, 2005).

Menurut Keller, Wille, Ramshorst, dan Werken (2002) dalam Suriadi, Sanada, Sugama, Thigpen, Kitagawa, Kinosita, et al. (2006), kejadian luka tekan di Intensive Care Unit (ICU) bervariasi antara satu hingga $56 \%$. Sekitar 60.000 pasien meninggal setiap tahun karena komplikasi yang berhubungan dengan luka tekan (Tschannen, Bates, Talsma, dan Ying 2012). Dari penelitian yang dilakukan oleh Suriadi et al. (2006), di salah satu rumah sakit di Indonesia dari 105 pasien yang dijadikan subyek penelitian, terdapat $33 \%$ pasien yang mengalami kejadian luka tekan. Angka kejadian luka tekan ini cukup tinggi sehingga risiko komplikasi yang dapat terjadipun semakin meningkat.

Luka tekan dapat meningkatkan durasi lamanya tinggal di rumah sakit atau LOS (length of stay) yang akan meningkatkan beban biaya rawat inap seiring dengan lamanya waktu tinggal di rumah sakit dan dapat menyebabkan kematian (Widodo,
2007; Compton, Hoffman, Hortig, Strau $\beta$, Frey, Zidek, et al., 2008). Selain itu, luka tekan memiliki dampak yang signifikan pada fungsi seseorang, kesehatan fisik dan mental, hubungan sosial, dan kualitas hidup (Gupta, Loong, dan Leong, 2011). Dampak yang ditimbulkan oleh luka tekan sangat buruk sehingga luka tekan harus mendapat perhatian khusus untuk dilakukan pencegahan.

Pencegahan luka tekan merupakan hal penting karena luka tekan sebenearnya dapat dicegah. Tujuan pencegahan luka tekan adalah untuk menurunkan lama dan/ atau jumlah tekanan dan robekan yang dipengaruhi oleh perlengkapan yang efektif atau tidak serta metode yang digunakan. Pencegahan luka tekan pada pasien-pasien yang berisiko seharusnya dilakukan secara berkesinambungan selama mereka berisiko mengalami luka tekan (European Pressure Ulcer Advisory Panel\&National Pressure Ulcer Advisory Panel, 2009 dalam Beeckman, Defloor, Schoonhoven, dan Vanderwee, 2011). Rumah sakit di Indonesia biasanya memiliki Standar Prosedur Operasional pencegahan luka tekan. Pelaksanaannya bergantung pada kebijakan dan kondisi di setiap rumah sakit.

Perawat merupakan petugas kesehatan yang berdekatan dengan pasien selama 24 jam dan bertemu dengan pasien-pasien yang berisiko mengalami luka tekan sehingga perawat memiliki peran penting dalam mencegah luka tekan. Bagi tenaga keperawatan, adanya luka tekan berarti peningkatan beban kerja karena luka tekan membutuhkan pendekatan perawatan yang berbeda (Kallman dan Suserud, 2009) sehingga dibutuhkan pencegahan berkesinambungan untuk mencegah terjadinya luka tekan. Perawat memainkan peran yang penting dalam pencegahan luka tekan (Tweed dan Tweed, 2008 dalam Strand dan Lindgren, 2010).

Pendekatan Theory of Planned Behavior (TPB) atau teori perilaku terencana dapat digunakan dalam menganalisis pencegahan luka tekan yang dilakukan oleh perawat. Ajzen (2006) menyatakan bahwa perilaku adalah manifestasi respon yang diberikan terhadap situasi yang dapat diobservasi. Anteseden terdekat dari perilaku adalah intensi, yaitu indikasi kesiapan seseorang 
Ristina Mirwanti: Intensi Perawat melakukan Pencegahan Luka Tekan

untuk menampilkan perilaku. Intensi berdasarkan pada antesedennya, yaitu sikap terhadap perilaku, norma subyektif, dan keyakinan dan pengendalian perilaku yang dirasakan (perceived behavioral controll PBC). Sikap berdasarkan pada keyakinan berperilaku, norma subyektif berdasarkan pada keyakinan normatif, dan pengendalian perilaku yang dirasakan berdasarkan pada keyakinan pengendalian. Untuk mengkaji intensi dan perilaku, penilaian langsung cukup dapat dilakukan pada sikap, norma subyektif, dan pengendalian perilaku yang dirasakan. Jika ingin mengetahui dasar dari faktor-faktor tersebut, merancang intervensi untuk mengubah perilaku yang efektif, maka perlu dikaji keyakinan berperilaku, normatif, dan pengendalian (Ajzen, 2011).

Intensi perilaku mencegah luka tekan yang dilakukan perawat dipengaruhi oleh sikap perawat terhadap pencegahan luka tekan, norma subyektif, dan pengendalian perilaku yang dirasakan oleh perawat dalam melakukan pencegahan luka tekan. Sikap perawat terhadap pencegahan luka tekan apakah favorable (mendukung) atau unfavorable (tidak mendukung). Norma subyektif yang dimaksud adalah fungsi dari keyakinan normatif yang menampilkan persepsi persetujuan seseorang secara spesifik untuk perawat melakukan atau tidak melakukan pencegahan luka tekan, apakah orang lain akan berpikir bahwa perawat seharusnya melakukan atau tidak melakukan perilaku pencegahan luka tekan. Sedangkan pengendalian perilaku yang dirasakan oleh perawat adalah persepsi perawat terhadap kemampuannya untuk melakukan pencegahan luka tekan.

Penekanan lebih dari dua jam dapat menyebabkan luka tekan dan pada kondisi pasien yang lebih buruk, luka tekan dapat terjadi lebih cepat (Morison, 2004). Adanya luka tekan di unit perawatan intensif dapat menurunkan kualitas mutu pelayanan di unit tersebut sehubungan dengan standar keselamatan pasien (Lumadi, 2011) sehingga pencegahan luka tekan penting dilakukan oleh perawat. Permasalahan pelaksanaan pencegahan luka tekan yang belum dilakukan dengan maksimal perlu diselesaikan, sehingga penting dilakukan penelitian untuk mengkaji anteseden terdekat perilaku yaitu intensi dan menganalisis hubungan antara sikap dengan intensi, norma subyektif dengan intensi, dan pengendalian perilaku yang dirasakan dengan intensi perawat dalam melakukan pencegahan luka tekan. Penelitian ini dengan menggunakan TPB karena TPB dapat diaplikasikan dan atau dijadikan landasan teori untuk melakukan penelitian perilaku dan antesedennya dalam berbagai bidang, termasuk perilaku perawat melakukan pencegahan luka tekan.

Penelitian ini bertujuan untuk mengetahui hubungan sikap dengan intensi perawat melakukan pencegahan luka tekan, norma subjektif dengan intensi perawat melakukan

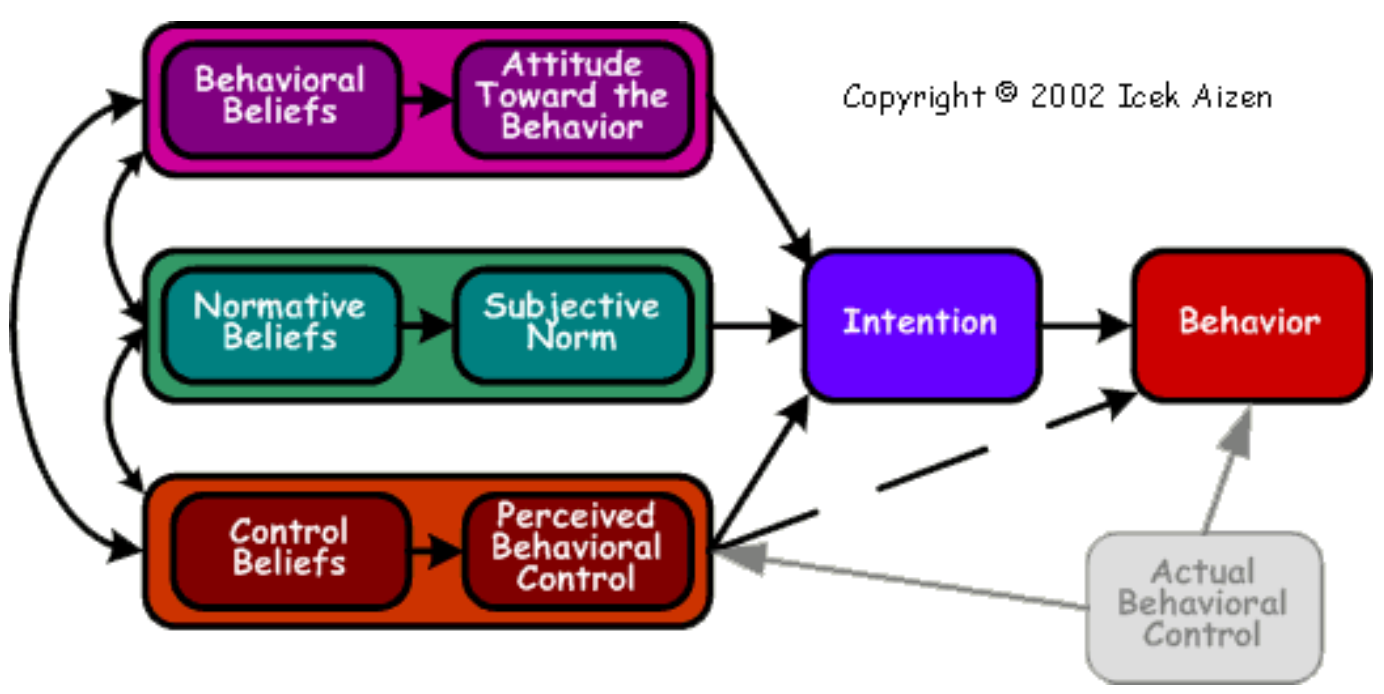

Bagan 1. Theory of Planned Behavior 
Ristina Mirwanti: Intensi Perawat melakukan Pencegahan Luka Tekan

pencegahan luka tekan, dan hubungan pengendalian perilaku intensi perawat melakukan pencegahan luka tekan. Hipotesis pada penelitian adalah terdapat hubungan antara sikap dengan intensi perawat melakukan pencegahan luka tekan, norma subjektif dengan intensi perawat melakukan pencegahan luka tekan, dan pengendalian perilaku intensi perawat melakukan pencegahan luka tekan.

\section{Metode Penelitian}

Penelitian kuantitatif ini menggunakan pendekatan korelasional. Penelitian ini dilakukan secara potong lintang (cross sectional). Penelitian ini dilakukan di ruang perawatan intensif dengan teknik total sampling yaitu seluruh perawat (70 perawat) yang melaksanakan asuhan keperawatan langsung pada pasien.

Pengumpulan data dilakukan dengan questioner data demografi dan questioner untuk mengkaji sikap, norma subyektif, dan pengendalian perilaku. Instrumen yang digunakan untuk mengkaji sikap adalah instrumen Attitude toward Pressure ulcer Prevention (APuP) yang telah divalidasi oleh Beeckman et al (2010) dengan indeks validitas konten dari setiap item pada APuP ini antara 0.87 dan 1.00 dan $\alpha$ Cronbach dalam rentang dari 0.76 hingga 0.81 . Instrumen ini diubah ke dalam Bahasa Indonesia menggunakan metode back translation. Hasil uji validitas dalam Bahasa Indonesia yaitu antara 0.34 dan 0.78 sehingga dinyatakan valid karena koefisien korelasi item terhadap total $\geq 0,3$ (Azwar, 2003). Hasil uji reliabilitas yaitu $\alpha$ Cronbach $=0.72$ yang berarti reliabilitas instrumen ini mencukupi (sufficient reliable).

Pengukuran terhadap norma subyektif, pengendalian perilaku, dan intensi dengan menggunakan kuesioner yang dikembangkan oleh peneliti berdasarkan konstruksi kuesioner TPB dan disesuaikan dengan standar prosedur operasional: prosedur pencegahan luka dekubitus di rumah sakit. Keseluruhan instrumen yang digunakan telah diuji reliabilitas dan validitas. Hasil uji validitas instrumen norma subyektif yaitu antara 0,67 dan 0,86 sehingga dinyatakan valid. Hasil uji reliabilitas yaitu $\alpha$ Cronbach 0,837 yang artinya reliabilitas instrumen ini kuat. Hasil uji validitas instrumen pengendalian perilaku antara 0,33 dan 0,77 sehingga dinyatakan valid. Hasil uji reliabilitasnya yaitu $\alpha$ Cronbach 0,859 yang berarti reliabilitas instrumen ini kuat. Hasil uji validitas instrumen intensi antara 0.37 dan 0.79 sehingga dinyatakan valid sedangkan asil uji reliabilitasnya yaitu $\alpha$ Cronbach 0.848 yang berarti reliabilitas intrumen ini kuat.

Penelitian ini telah dilakukan dengan mempertimbangkan prinsip etik yang berlaku. Peneliti memberikan informasi mengenai tujuan dan manfaat penelitian kepada responden. Responden diberikan kebebasan untuk mengikuti ataupun tidak penelitian. Responden yang bersedia dipersilakan memberikan tanda tangan pada lembar informed consent. Data responden dirahasiakan dan hanya digunakan untuk kepentingan penelitian.

Analisis data dilakukan secara univariabel dan bivariabel. Data karakteristik responden seperti jenis kelamin, tingkat pendidikan, dan status kepegawaian menggunakan presentase, sedangkan usia dan lama kerja menggunakan mean. Analisis bivariabel dilakukan untuk mengetahui hubungan antarvariabel. Analisis bivariabel dengan menggunakan Rank Spearman karena distribusi variabel sikap, norma subyektif, pengendalian perilaku, dan intensi tidak terdistribusi normal.

\section{Hasil Penelitian}

Tabel 1, terlihat bahwa sebagian besar perawat berjenis kelamin perempuan $(68,6 \%)$, berpendidikan DIII Keperawatan (70\%), dan hampir keseluruhan responden adalah PNS (92,9\%). Rentang usia responden yaitu 25 - 55 tahun dengan mean 33,86 tahun dan rentang lama bekerja $2-30$ tahun dengan mean 10,67 tahun, tampak pada tabel 2 .

Berdasarkan tabel 3, rentang sikap responden yaitu 34-49 dengan mean 40,80, rentang norma subyektif responden 15-24 dengan mean 19,71 , rentang $\mathrm{PBC}$ responden 32-57 dengan mean 45,44, dan rentang.

Hasil penelitian menunjukkan terdapat hubungan antara sikap $(\mathrm{r}=0,63, \mathrm{p}<0,05)$, 
Ristina Mirwanti: Intensi Perawat melakukan Pencegahan Luka Tekan

Tabel 1 Frekuensi dan Presentase Jenis Kelamin, Tingkat Pendidikan, Status Kepegawaian Perawat di Ruang Perawatan Intensif $(n=70)$

\begin{tabular}{llcc}
\hline \multicolumn{1}{c}{ Karakteristik } & \multicolumn{1}{c}{ Jenis } & f & Persentase \\
\hline Jenis Kelamin & Perempuan & 48 & 68,6 \\
\multirow{2}{*}{ Pendidikan } & Laki - laki & 22 & 31,4 \\
& DIII & 49 & 70 \\
\multirow{2}{*}{ Status Kepegawaian } & S1 & 21 & 30 \\
& PNS & 65 & 92,9 \\
& Kontrak & 5 & 7,1 \\
\hline
\end{tabular}

Tabel 2 Rata-rata Usia dan Lama Kerja Perawat di Ruang Perawatan Intensif $(\mathbf{n}=\mathbf{7 0})$

\begin{tabular}{|c|c|c|}
\hline Variabel & Mean (SD) & Median (Rentang) \\
\hline Usia & $33,86(6,0)$ & $33(25-55)$ \\
\hline Lama kerja & $10,67(6,5)$ & $10(2-30)$ \\
\hline
\end{tabular}

Tabel 3 Distribusi Skor Sikap, Norma Subyektif, PBC, dan Intensi Perawat terhadap Pencegahan Luka Tekan di Ruang Perawatan Intensif $(n=70)$

\begin{tabular}{lccc}
\hline \multicolumn{1}{c}{ Variabel } & Mean \pm SD & Median (Rentang) & Skor Maksimal \\
\hline Sikap & $40,80 \pm 3,6$ & $41(34-49)$ & 52 \\
Norma Subyektif & $19,71 \pm 2,4$ & $19(15-24)$ & 24 \\
PBC & $45,44 \pm 4,2$ & $45(32-57)$ & 60 \\
Intensi & $47,87 \pm 5,0$ & $45,5(42-60)$ & 60 \\
\hline
\end{tabular}

Tabel 4 Hubungan antara Sikap, Norma Subyektif, PBC dengan Intensi Perawat dalam Melaksanakan Pencegahan Luka Tekan di Ruang Intensif

\begin{tabular}{lcc}
\hline \multicolumn{1}{c}{ Variabel } & \multicolumn{2}{c}{ Intensi } \\
\cline { 2 - 3 } & $\mathbf{r}$ & Nilai $\boldsymbol{p}$ \\
\hline Sikap & 0,632 & 0,000 \\
Norma Subyektif & 0,625 & 0,000 \\
PBC & 0,633 & 0,000 \\
\hline $\mathbf{\alpha = 0 , 0 5}$ & &
\end{tabular}

norma subyektif $(\mathrm{r}=0,625, \mathrm{p}<0,05)$, dan PBC $(r=0,633, p<0,05)$ dengan intensi responden dalam melakukan pencegahan luka tekan yang artinya semakin favorable sikap, semakin tinggi norma subyektif dan PBC responden dalam melakukan pencegahan luka tekan, maka semakin tinggi pula intensi responden untuk melaksanakan pencegahan luka tekan.

\section{Pembahasan}

Hasil penelitian ini sesuai dengan konsep TPB bahwa sikap merupakan anteseden intense, terdapat hubungan antara sikap dengan intensi perawat yang bersifat positif. Hal ini berarti semakin favorable (mendukung) sikap perawat terhadap pencegahan luka tekan maka semakin tinggi pula intensi perawat untuk melakukannya.

Rata-rata perawat memiliki sikap yang cenderung mendukung terhadap pencegahan luka tekan pada pasien kritis di ruang intensif. Hal ini sejalan dengan hasil penelitian di Irlandia, Swedia, dan Belgia yang mengkaji sikap perawat menunjukkan bahwa perawat memiliki sikap yang positif terhadap 
Ristina Mirwanti: Intensi Perawat melakukan Pencegahan Luka Tekan

pencegahan luka tekan (Moore dan Price, 2004; Kallman dan Suserud, 2009; Strand dan Lindgren, 2010; Beeckman et al, 2011). Sikap perawat yang positif terhadap pencegahan luka tekan diharapkan akan diikuti dengan intensi perawat untuk melakukan pencegahan luka tekan.

Sikap perawat terhadap pencegahan luka tekan ditentukan oleh kepercayaan perawat mengenai konsekuensi ketika melakukan pencegahan luka tekan dan ditimbang berdasarkan hasil evaluasi terhadap konsekuensi yang akan terjadi ketika melakukan pencegahan luka tekan. Konsekuensi yang dapat terjadi adalah meminimalisir kejadian luka tekan pada pasien. Pasien dengan faktor resiko luka tekan yang tidak mendapat tindakan pencegahan luka tekan dapat mengalami luka tekan. Dampak dari luka tekan adalah meningkatnya angka morbiditas dan mortalitas (Salcido, 2012). Adanya kejadian luka tekan di ruang perawatan intensif juga memberikan dampak yang negatif bagi ruang perawatan yaitu dapat menurunkan kualitas mutu pelayanan di unit tersebut sehubungan dengan standar keselamatan pasien (Lumadi, 2012). Pasien yang tidak menderita luka tekan, akan memiliki kualitas hidup pada dimensi fisik dan psikologis yang lebih baik.

Kejadian luka tekan di ruang perawatan akan memberikan dampak kepada beban kerja perawat. Menurut D'hoore, Guisset, dan Tilquin (1997) adanya kejadian luka tekan secara signifikan memengaruhi beban kerja perawat. Semakin tinggi kejadian luka tekan, makabebankerja perawatakan semakin tinggi. Beban kerja perawat yang semakin tinggi akan berdampak pada meningkatnya waktu perawatan terhadap pasien dan peningkatan biaya. Beban kerja yang meningkatpun dapat kembali meningkatkan kejadian luka tekan Beban kerja perawat diidentifikasi sebagai salah satu faktor resiko yang berhubungan dengan kejadian luka tekan (Cremasco, Wenzel, Zanei, dan Whitaker, 2013). Beban kerja dan luka tekan seperti lingkaran sebab akibat yang tidak terputus. Akan tetapi di sisi lain, beban kerja perawat dapat juga dianggap sebagai prediktor yang signifikan yang dapat menurunkan kejadian luka tekan yang terjadi di rumah sakit (Aydin, Donaldson, Stotts, Fridman, dan Brown, 2015). Persepsi terhadap konsekuensi ini dapat memengaruhi sikap perawat terhadap perilaku pencegahan luka tekan, sehingga sikap perawat akan mendukung terhadap pencegahan luka tekan.

Penelitian ini, sikap perawat lebih mendukung terhadap pelaksanaan pencegahan luka tekan dilihat dari lama kerja perawat. Perawat yang bekerja lebih dari lima tahun rata-rata sikap lebih favorable dibandingkan dengan yang bekerja kurang dari lima tahun. Berdasarkan hasil penelitian Beeckman et al. (2011) setelah lima tahun bekerja, semakin lama perawat bekerja maka sikap perawat terhadap pecegahan luka tekan cenderung semakin favorable. Semakin lama masa kerja perawat maka akan semakin banyak pengalaman perawat. Menurut Azwar (1995) salah satu faktor yang memengaruhi sikap adalah pengalaman. Begitu juga salah satu faktor yang memengaruhi sikap perawat terhadap pencegahan luka tekan adalah pengalaman pribadi perawat. Sehingga semakin lama masa kerja perawat, maka akan semakin banyak luka tekan yang dilihat oleh peraat, sehingga sikap perawat akan semakin mendukung pencegahan luka tekan.

Samuriwo (2010) menyatakan bahwa pendidikan, pelatihan, dan pencegahan luka tekan hanya efektif ketika perawat telah melihat pasien dengan luka tekan. Pada pasien kritis dengan kondisi penyakit yang sama, pasien dengan luka tekan membutuhkan perawatan yang lebih banyak dibandingkan pada pasien yang tidak mengalami luka tekan. Perawatan luka tekan dapat meningkatkan beban kerja perawat. Semakin sering merawat pasien dengan luka tekan, maka akan semakin meningkat beban kerja yang dirasakan oleh perawat. Pengalaman perawat dalam merawat pasien dengan luka tekan dapat meningkatkan keyakinan perawat untuk melakukan pencegahan luka tekan pada pasien kritis dengan tujuan untuk menghindarkan pasien dari luka tekan, sehingga pasien yang bebas dari luka tekan tidak akan meningkatkan beban kerja perawat.

Penelitian ini, sebagian besar responden berjenis kelamin perempuan dan rata-rata sikap responden perempuan cenderung lebih favorable dibandingkan dengan responden laki-laki. Hal ini berbeda dengan hasil penelitian Beeckman et al. (2011) 
Ristina Mirwanti: Intensi Perawat melakukan Pencegahan Luka Tekan

yang menunjukkan bahwa sikap responden laki-laki terhadap pencegahan luka tekan cenderung favorable dibandingkan dengan sikap responden perempuan. Hal ini dapat disebabkan karena jumlah responden perempuan lebih banyak.

Hasil penelitian juga menunjukkan ratarata sikap perawat cenderung lebih favorable (mendukung) pada tingkat pendidikan DIII Keperawatan. Hal ini berbeda dengan penelitian Beeckman et al. (2011) yaitu semakin tinggi jenjang pendidikan perawat maka sikap perawat semakin cenderung favorable. Hal ini dapat disebabkan karena pada penelitian ini sebagian besar jumlah responden dengan tingkat pendidikan DIII Keperawatan. Menurut Samuriwo (2010), pendidikan mengenai luka tekan dan pencegahan hanya akan efektif ketika perawat telah memiliki pengalaman bertemu pasien dengan luka tekan. Hal ini berarti pendidikan tidak memiliki peran tunggal tetapi dapat dipengaruhi pengalaman dan masa kerja dalam memengaruhi sikap perawat.

Hasil penelitian menunjukkan, semakin tinggi motivasi perawat mematuhi tekanan normatif untuk melakukan pencegahan luka tekan, maka semakin tinggi pula intensi perawat untuk melakukan pencegahan luka tekan. Penelitian ini, tekanan normatif pada perawat untuk melakukan pencegahan luka tekan dapat berasal dari kepala ruangan, dokter penanggung jawab pasien, dan rekan perawat lain di ruangannya.

Hasil penelitian juga menunjukkan tingginya persepsi perawat bahwa dokter, kepala ruangan, dan rekan sejawatnya mendukung perawat melakukan pencegahan luka tekan sehingga perawat cenderung akan menampilkan perilaku pencegahan luka tekan melalui tingginya intensi pencegahan luka tekan. Persepsi ini dapat didasari oleh tingginya perhatian dokter, perawat, dan kepala ruangan terhadap pencegahan luka tekan pada pasien kritis di ruang intensif sehingga akan memberikan penekanan pada pelaksanaan pencegahan luka tekan. Hal ini menunjukkan pentingnya adanya tekanan dari orang yang memiliki kekuatan atau atasan mengenai pencegahan luka tekan sebagai bagian perawatan harian bagi pasien di ruang perawatan intensif (Strand dan Lindgren, 2010) sehingga dapat meningkatkan intensi perawat untuk melakukan pencegahan luka tekan.

Penelitian ini, rata-ata skor norma subyektif yang tinggi terhadap pencegahan luka tekan yang menunjukkan tingginya motivasi responden untuk mengikuti tekanan normatif yang berasal dari sekitar perawat. Salah satu tekanan normatif berasal dari dokter penanggung jawab pasien. Hal ini memberikan gambaran bahwa pentingnya peran profesi lain dalam pelaksanaan pencegahan luka tekan pada pasien kritis di ruang intensif.

Penelitian ini, semakin perawat merasa perilaku pencegahan luka tekan di bawah pengendaliannya, maka akan semakin tinggi pula intensi perawat untuk melakukan pencegahan luka tekan pada pasien kritis di ruang perawatan intensif. Perawat juga cenderung merasa yakin untuk mengendalikan dan melakukan pencegahan luka tekan. Persepsi seseorang terhadap kemampuan untuk melakukan sesuatu dipengaruhi oleh kemudahan dan kesulitan yang dirasakan (Ajzen \& Cote, 2008 dalam Strand \& Lindgren, 2010). Persepsi perawat terhadap kemampuan untuk melakukan pencegahan luka tekan juga dipengaruhi oleh kemudahan dan kesulitan yang dirasakan dalam melakukan pencegahan luka tekan. Beberapa contoh kemudahan atau hal penunjang yang dirasakan adalah tersedianya alat, perlengkapan dan fasilitas untuk mengurangi tekanan, seperti kasur angin; pengetahuan; waktu; kinerja tim yang baik; dan jumlah staf yang mencukupi. Hambatan yang dirasakan perawat dalam melakukan pencegahan luka tekan antara lain kurangya jumlah perawat; kurangnya waktu yang ada; kondisi pasien yang tidak kooperatif, kondisi yang parah, atau hemodinamik yang tidak stabil; kurangnya sumber daya dan perlengkapan untuk melakukan pencegahan luka tekan; kurangnya pengetahuan; dan situasi kerja yang menegangkan/stressful (Moore dan Price, 2004; Kallman dan Suserud, 2009; Strand dan Lindgren, 2010. Rata-rata skor $\mathrm{PBC}$ responden laki-laki lebih tinggi jika dibandingkan dengan responden perempuan. Responden laki-laki akan memiliki keyakinan yang lebih tinggi untuk mampu melakukan pencegahan luka tekan. Salah satu contoh pencegahan luka tekan 
Ristina Mirwanti: Intensi Perawat melakukan Pencegahan Luka Tekan

seperti mobilisasi progresif pada pasien, responden laki-laki memiliki fisik yang cenderung lebih besar dan lebih kuat jika dibandingkan dengan responden perempuan, sehingga laki-laki akan lebih merasa mampu untuk melakukan pencegahan luka tekan.

Rata-rata skor PBC pada responden dengan tingkat pendidikan S1 Keperawatan lebih tinggi jika dibandingkan dengan responden berpendidikan DIII. Pengendalian yang dirasakan seseorang salah satunya dipengaruhi oleh pengetahuan (Nash et al., 1993 dalam Moore dan Price, 2004) dan berdasarkan penelitian Beeckman et al. (2011) semakin tinggi jenjang pendidikan perawat, maka semakin tinggi pula pengetahuan perawat terhadap pencegahan luka tekan. Sehingga secara tidak langsung pengendalian perilaku yang dirasakan perawat terhadap pencegahan luka tekan juga dipengaruhi oleh tingkat pendidikan perawat.

Responden yang bekerja lebih dari lima tahun memiliki rata-rata skor PBC yang lebih tinggi jika dibandingkan dengan responden yang bekerja kurang atau sama dengan lima tahun. Hal ini juga tampak pada intensi responden yang dengan rata-rata lebih tinggi pada responden yang bekerja lebih dari 5 tahun. Pengalaman bekerja akan memberikan keyakinan bahwa perawat mampu melakukan pencegahan luka tekan sehingga intensi perawat akan tinggi untuk melakukan pencegahan luka tekan. Lama pengalaman perawat merawat pasien merupakan salah satu aspek untuk melihat keahlian seorang perawat. Keahlian perawat merupakan salah satu indikator yang signifikan terhadap penurunan kejadian luka tekan di rumah sakit (Aydin et al., 2015).

Pengendalian perilaku yang dirasakan oleh perawat dipengaruhi oleh hal-hal yang dirasakan mempermudah dan mempersulit perawat dalam melakukan pencegahan luka tekan. Berdasarkan presentase tertinggi, maka kemudahan (opportunities) yang dirasakan oleh perawat dalam melakukan pencegahan luka tekan antara lain tersedianya alat, perlengkapan dan fasilitas untuk mengurangi tekanan, seperti kasur angin; pengetahuan; waktu; kinerja tim yang baik; dan jumlah staf yang mencukupi (Kallman dan Suserud, 2009; Strand dan Lindgren, 2010). Hambatan tertinggi yang dirasakan perawat dalam melakukan pencegahan luka tekan antara lain kurangya jumlah perawat; kurangnya waktu yang ada; kondisi pasien yang tidak kooperatif, kondisi yang parah, atau hemodinamik yang tidak stabil; kurangnya sumber daya dan perlengkapan untuk melakukan pencegahan luka tekan; kurangnya pengetahuan; dan situasi kerja yang menegangkan (Moore dan Price, 2004; Strand dan Lindgren, 2010).

\section{Simpulan}

Penelitian ini, terdapat hubungan antara sikap dengan intense, norma subyektif dengan intense, dan pengendalian perilaku dengan intense peraat dalam melakukan pencegahan luka tekan di uang perawatan intensif. Untuk meningkatkan intensi perawat dalam melakukan pencegahan luka tekan, maka pihak rumah sakit perlu meningkatkan pengetahuan perawat mengenai pencegahan luka tekan untuk meningkatkan sikap favorabel perawat terhadap pencegahan luka tekan; melakukan supervisi terhadap pelaksanaan pencegahan luka tekan dan melakukan pendekatan interdisiplin dalam melakukan pencegahan luka tekan untuk meningkatkan norma subyektif perawat; dan meningkatkan hal-hal yang mempermudah perawat dalam melakukan pencegahan luka tekan untuk meningkatkan pengendalian perilaku yang dirasakan perawat.

\section{Daftar Pustaka}

Ajzen, I. (2006). TPB Diagram. Melalui http://people.umass.edu/aizen/tpb.diag.html pada Maret 2013.

Ajzen, I. (2011). Frequently Asked Questions. Melalui http://people.umass.edu/aizen/faq. html pada Maret 2013.

Aydin, C., Donaldson, N., Stotts, N.A., Fridman, M., Brown, D.S. (2015). Modeling hospital-acquired pressure ulcer prevalence on medical-surgical units: nurse workload, expertise, and clinical processes of care [Abstract]. Health Serv Res,50(2), 351 - 73. 
Ristina Mirwanti: Intensi Perawat melakukan Pencegahan Luka Tekan

Doi: 10.1111/1475-6773.12244.

Azwar, S. (1995). Sikap Manusia: Teori dan Pengukurannya Edisi Ke-2. Yogyakarta : Pustaka Pelajar.

Beeckman, D., Defloor, T., Demarre, L., Hecke, A.V., Vanderwee, K. (2010). Pressure ulcers: Development and psychometric evaluation of the Attitude towards Pressure ulcer Prevention instrument (APuP). International Journal of Nursing Studies 47 (2010) 1432-1441, Elsevier Ltd, doi: 10.1016/j.ijnurstu.2010.04.004.

Beeckman, D., Defloor, T., Schoonhoven, L., \& Vanderwee, K. (2011). Knowledge and Attitudes of Nurses on Pressure Ulcer Prevention: A cross-Sectional Multicenter Study in Belgian Hospitals. Worldviews on Evdence Based Nursing, Third Quarter 2011, Sigma Theta Tau International, doi: 10.1111/j.1741-6787.2011.00217.x

Bergstrom, N. (2005). Patients at Risk for Pressure Ulcers and Evidence-Based Care for pressure Ulcer Prevention. In D. Bader, C. Bouten, D. Colin, \& C. Oomens (Eds.), Pressure Ulcer Research : Current and Future Perspectives (pp 35-50). New York : Springer.

Cremasco, M.F., Wenzel, F., Zanei, S.S., Whitaker, I.Y. (2013). Pressure ulcers in the intensive care unit: the relationship between nursing workload, illness severity and pressure ulcer risk [Abstract]. J Clin Nurs, 22(15-16), $2183-91$.

Compton, F., Hoffman, F., Hortig, T., Strau $\beta$, M., Frey, J., Zidek, W., \& Schafer, J-H. (2008). Pressure Ulcer Predictors in ICU Patients: Nursing Skin Asessment Versus Objective Parameters. Journal of Wound Care, 17(10)

Cox, J. (2011). Predictors Of Pressure Ulcers In Adult Critical Care Patients. American Journal Of Critical Care, 20,(5), pp. 364375.

D'hoore, W., Guisset, A.L., Tilquin, C. 1997. Increased nursing-time requirements due to pressure sores in long-term-care residents in Quebec [Abstract]. Clin Perform Qual Health Care, 5(4), 189-94.

Depkes.(2006). Standar Pelayanan Keperawatan di ICU. Diunduh dari http://perpustakaan.depkes.go.id:8180/ handle/123456789/760

Elliot, R., McKinley, S., \& Fox, V. (2008). Quality Improvement Program to Reduce The Prevalence of Pressure Ulcers in an Intensive Care Unit. American Journal of Critical Care, 17, 328-337.

Gupta, N., Loong, B., \& Leong, G. (2012). Comparing and contrasting knowledge of pressure ulcer assessment, prevention and management in people with spinal cord injury among nursing staff working in two metropolitan spinal units and rehabilitation medicine training specialists in a three-way comparison. Spinal Cord, 50, 159-164.

Kallman, U. \& Suserud, B-Oasa. (2009). Knowledge, attitudes and practice among nursing staff concerning pressure ulcer prevention and treatment - a survey in a Swedish healthcare setting. Journal Compilation, 2009, Nordic College of Caring Science, doi: 10.1111/j.14716712.2008.00627.x

Lumadi, S.A. (2011). Hubungan pengetahuan dan ketrampilan perawat dalam melakukan mobilisasi dengan terjadinya ulkus tekan pada pasien di ruang GICU RSUP Dr. Hasan Sadikin Bandung. Universitas Padjadjaran, Bandung.

Moore, Z. \& Price, P. (2004). Nurses' attitudes, behaviours and perceived barriers towards pressure ulcer prevention. Journal of Clinical Nursing, 13, 942-951, Blackwell Publishing.

Morison, M. J. (2004). Manajemen Luka. Jakarta: EGC.

National Pressure Ulcer Advisory Panel (NPUAP). (2012). NPUAP Pressure Ulcer Stages/Categories. Diunduh dari http:// www.npuap.org/resources/educational-and- 
Ristina Mirwanti: Intensi Perawat melakukan Pencegahan Luka Tekan

clinical-resources/npuap-pressure-ulcerstagescategories/

Salcido, R., Popescu,A., Potter, P. J., Talavera, F., Kolaski, K., Allen, K. L., \& Lorenzo C. T. (2012). Pressure Ulcer and Wound Care. Diunduh dari http://emedicine.medscape. com/article/319284-overview\#aw2aab6b2.

Samuriwo, R. (2010). Effects of education and experience on nurses' value of ulcer prevention. Bristish Journal of Nursing, 19(20).

Strand, T., \& Lindgren, M. (2010).Knowledge, attitudes, and barriers towards prevention of pressure ulcers in intensive care units : a descriptive cross-sectional study. Intensive and Critical Care Nursing, 26, 335-342,
Elsevier, doi: 10.1016/j.iccn.2010.08.006.

Suriadi, Sanada, H., Sugama, J., Thigpen, B., Kitagawa, A., Kinosita, S., \& Murayama, S. (2006).A new instrument for predicting pressure ulcer risk in an intensive care unit. Journal Of Tissue Viability, 16(3), 21-26.

Tschannen, D., Bates, O., Talsma, A., \& Ying, G. (2012). Patient-Specific And Surgical Characteristics In The Development Of Pressure Ulcers', American Journal of Critical Care, 21(2), 116-125.

Widodo, Arif.(2007). Uji Kepekaan Instrumen Pengkajian Risiko Dekubitus Dalam Mendeteksi Dini Risiko Kejadian Dekubitus Di RSIS. Sains dan Teknologi, 8 (1), 39-54, ISSN 1411-5174 